\title{
Export Intention of Small and Medium Tunisian Enterprises
}

\author{
Mouna Baccour-Hentati \\ University of Sfax, Sfax, Tunisia
}

\begin{abstract}
Due to globalization, export is considered as an essential asset for the continuity and profitability of businesses. Nevertheless, export is a complex process. To initiate and to develop this strategy, a business must clear away the internal and external constraints and take advantage of the stimulating factors. The latters show up at each stage of the process. These stimuli are especially decisive during pre - export behavior or the intention stage. So the export intention is explained by some variables: the differential advantages, the organizational predisposition and the perception of the risk. Our conceptual model has been applied on a sample of small and medium Tunisian enterprises (SME). Inspiring by churchill's methodology, our principal conclusion is that export is the strategy implying less capital and risk than the other modes of entry. However this decision may turn up like suicidal if the firm having the intention to export doesn't proceed by an assessment of its export.
\end{abstract}

Keywords: Export intention, competitive advantages, organizational predisposition and risk.

\section{Introduction}

With this wave of globalization and liberalization of exchanges that characterizes today's world, enterprises are bound to take into account the global market. In this perspective, the Tunisian enterprises which are mostly SME needed to adopt strategies of internationalisation through the exports since such a strategy involves less capital and commercial and financial risk than other modes of entry. But, such a necessity can appear like a hazardous or suicidal decision if the enterprise having the intention to export does not start by assessing its potential of export.

In this field several researchers raised the problem of the behavior hardback pre export to the intention to export like Wiedersheim - Paul and Welch (1978). The latter is defined by Reid (1981) as being the motivation, the behavior, beliefs and waiting opposite the contribution of the export to the growth of the business.

Copyright (C) 2010 Mouna Baccour-Hentati. This is an open access article distributed under the Creative Commons Attribution License unported 3.0, which permits unrestricted use, distribution, and reproduction in any medium, provided that original work is properly cited.

Author contact Mouna Baccour-Hentati, e-mail: mouna_baccour_hentati@laposte.net
Our issue resides in the explanation of the intention to export through three factors, the differential advantages, the organizational predisposition of the business and the risk discerned all while doing its empiric analysis in the case of the Tunisian SME.

The objectives of our article are the following:

- To develop a model in order to explain the intention to export for the Tunisian SME;

- To determine empirically what makes the difference empirically between those who have the intention to export and those do not. 
A review of the literature followed by the description of the model, the adopted methodology and the main results will are presented:

\section{The literature Review}

\subsection{Schools of thoughts}

Studies on the behavior of export increased to generate two big schools of research. The first focuses on the explanatory factors of success in exports while the second is interested in the export process, Eugene and Pasternack (1994).

\subsubsection{The explanatory factors of success:}

The explanatory factors of the export success are tributary to the organizational features of the business and the strategy of export marketing:

- For the organizational features of the business, researchers mentioned the size of the business, Louter (1991), Dicht and al (1986), Ogram (1982); Resources of the business that represent a determinant decision of the export behaviour, Weinrauch and Rao (1974), Cavusgil (1984) ...etc, managerial expectations where the action of top management on export decisions is an obvious success. So managers tend to base their expectations on the profitability, risk, the cost of the export from the experience of their businesses and of the other and their perceptions of the potential impact of the perceptual environment change, Cavusgil (1984).

- For the strategy of export marketing, it implies several measurements namely the expansion and the commercial competitiveness. Besides the scheduling and the manner, whose function marketing is organized, reflect this strategy, Louter (1991).

\subsubsection{The process of export}

We can consider in this setting two groups of researchers Johnson and Czinkotas (1982):

- The first has been interested in motives that push and attract managers to opt for the internationalisation through the export. These motives are of double nature. Proactive motives indicating an aggressive export behaviour such as the differential advantages, the growth through the expansion of the market and the opportunity of the profit Eugene and Pasternack (1994), Leonidas (1995) ...etc., on the other hand, the reactive motives refer to the passive engagement in the export as answers to environnemental pressures such as overproduction and the reduction of local sales Eugene and Pasternack (1994).

- The second shows that decisions to export take place in a set of stages where each represents a raised degree of engagement of the business in the export. Among these stages, it mentions the effect of the experience (the effect of training) and success in the reach of the objectives, Barker (1992) and Jouy (1993) ...etc.

\section{The description of the explanatory model}

\subsection{The export intention}

Ajsen and Fishbein (1980) based themselves on the measure of the intention to operate a given action in order to foresee the future behavior. According to these authors the intention of the individual to fulfil a given act depends essentially on his attitude towards his governing norms, on his behavior and motivation to conform himself to these norms.

Let's move to the case of the firm, Reid (1981) defined the export intention as being the motivation, the behavior, beliefs and expectations towards the contribution of the export to the growth of the business. 
Cavusgil (1984) affirms that there is a relation between the intention to export and the organizational features associated to the export. Louter (1991) sees that the most important factor to explain the intention to export is the managerial attitude towards the export. Yang and Alden (1992) found a relation between the intention to export, the capacity of the expansion of the market, gates to the export, the differential advantages, the organizational predisposition and the perception of the relative risk to the export. In the light of what has been advanced, we notice that most researchers mention the following variables to explain the intention to export.

- The differential advantages,

- The organizational predisposition,

- $\quad$ The perception of the risk.

We analyze in what follows every variable.

\subsection{The differential advantages}

These differential advantages are considered at two levels, the country and the business.

Porter (1990) found that the competitive advantage of a country influences the competitive capacity of business on the international market through the natural resources, the development of the country, the maturity of infrastructure and telecommunications, the quality of research and the development, the bases of knowledge and the requirement of the local demand in terms of innovation.

At the level of the firm, an important number of researchers underlined the importance of certain features of the business at this level; good combination product/market, skills and resources, competitive prices, technological advancement, flexibility in relation to changes..., Yang and Alden (1992)...etc.

We can already propose the following hypothesis 1 :
H1: The differential advantages are positively bound to the export intention.

\subsection{The organizational predisposition}

This concept involves several senses; knowledge, attitudes and intentions, motivations, perceptions, knowledge, faculties and managerial expectation towards the export, the organizational culture favourable or unfavourable Eugene and Pasternack (1994), Louter (1991), Kaufmann and Schmidt (1994), the training in the export or the unsuitability of the export experience, the degree of responsibility and managerial engagement, Constantines and Morgan (1994), Yang and Alden (1994).

When, the second hypothesis is stipulated:

H2: The organizational predisposition can be bound positively or negatively to the export intention.

\subsection{The discerned risk}

The perception of the export risk affects managerial strategies extensively. For this reason businesses must consider the total international risk in the conception of any internationalisation strategy. This risk includes the uncertainty of the environment (political risk, natural risk...etc.), the uncertainty of the industry (change of tastes and preferences, the apparition of substitutable products, competition, change of the technology...etc.) and, in short, appearancethe operational, financial or behavioral uncertainties,...etc. Muller (1992), Johnson and Czinkota (1982) identified a set of factors of risk affecting negatively the attitude towards export among others, the lack of information, the lack of adequacy of the staff, of the financial and commercial resources, the physical distance and cross culture...etc.

We can express the third hypothesis:

H3: The discerned risk is associated negatively to the export intention. Thus, the conceptual model is as follows: 


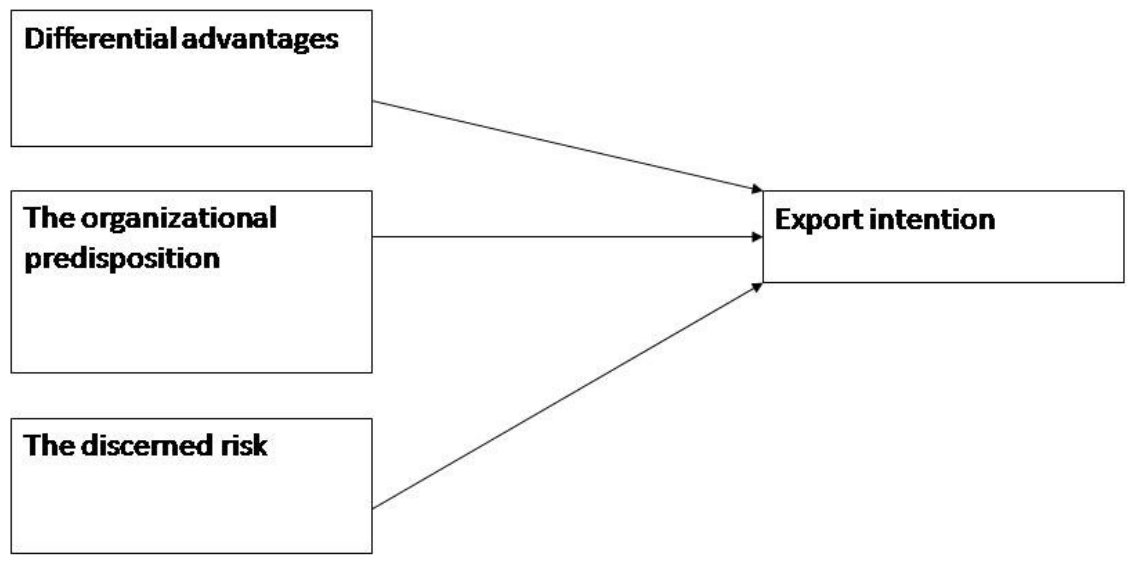

Fig1. The conceptual model

Moderator Variable is the experience or the training in the export

This model will be empirically tested on the Tunisian SME while following our methodology of inspired research of Churchill's works (1979).

\section{Research methodology}

We refer to Churchill's paradigm (1979), whose stages are:

- To specify the domain of constructs (stage already established theoretically)

- To generate a sample of items,

- To purify measures (tests of unidimensionality and reliability)

- To ascertain the new measures' reliability,

- To test of the validity of constructs,

- To develop norms.

\subsection{Genesis of an item sample}

This stage is achieved in four phases:

- Proposition of measures for each construct: The dependent variable, the export intention (IE), is measured by a scale of Likert of 5 points going from "very strong intention" to" no intention ", Eugene and Pasternack (1994). We suppose that those having the strong intention will be invited to answer the other questions (see Appendix 1). The first independent variable
" differential Advantages" (AD), has been measured by 36 measured items on a scale of Likert of 5 points going from " quite okay " to " Not at all okay " according to Eugene and Pasternack (1994), (see Appendix 2). The second independent variable "organizational Predisposition" (PO), has been measured by 22 items on a scale of Likert of 5 points, Eugene and Pasternack (1994), (see Appendix 3). Finally, for the third independent variable "discerned risk" (R), we propose only one question, measured on a scale of Likert of 5 points going from " the strongest " to " the weakest ", (see Appendix 4).

- The choice of the scale of Likert is justified, since methodological efficiency is satisfactory. Its operational efficiency is good for its simplicity (comprehensible). This scale is much recommended in domains of behaviour and psychology, Vernette (1991).

- An investigation test has been led by 9 SME, three belonging to the Textile sector and Clothing, three to the sector of leather and shoes and the last three to the food sector. These SME chosen by judgment are based in the region of Sfax. This investigation test was very useful to test the vocabulary employee, the length of the progress of the questions...etc. 
- The choice of a final sample: the latter involves 88 chosen enterprises according to suitability whose features are summed up in Table 1.

Table 1: Characteristics of the sample

\begin{tabular}{|c|c|c|c|c|}
\hline Characteristics & \multicolumn{4}{|c|}{ Distributions } \\
\hline Sectoriels & Textile $(34.1 \%)$ & $\begin{array}{l}\text { Leather and } \\
\text { shoes }(35.2 \%)\end{array}$ & \multicolumn{2}{|c|}{ various $(30.7 \%)$} \\
\hline Legal shape & \multicolumn{2}{|l|}{$\ll \mathrm{SA} »(19.3 \%)$} & \multicolumn{2}{|c|}{ «SARL » $(80.7 \%)$} \\
\hline effectif & \multicolumn{2}{|c|}{ More than $50(30 \%)$} & \multicolumn{2}{|c|}{ Less than $50(70 \%)$} \\
\hline Social Capital & $\begin{array}{l}<\text { à 150.000DT } \\
(60 \%)\end{array}$ & $\begin{array}{l}\text { Enter } \\
\text { 150.000DT and } \\
1 \text { Billion }(20 \%)\end{array}$ & \multicolumn{2}{|c|}{$\begin{array}{l}\text { More thane } 1 \text { Billion } \\
(20 \%)\end{array}$} \\
\hline $\begin{array}{l}\text { Business Cipher in } \\
97\end{array}$ & $\begin{array}{l}\text { Less thane } \\
1 \text { Billion }(60 \%)\end{array}$ & $\begin{array}{l}\text { enter } 1 \text { and } 10 \\
\text { Billions }(35 \%)\end{array}$ & \multicolumn{2}{|c|}{ More than 10 Billions (5\%) } \\
\hline $\begin{array}{l}\text { Business Cipher in } \\
96\end{array}$ & $\begin{array}{l}\text { Less than } \\
\text { 1Milliard } \\
(70 \%)\end{array}$ & $\begin{array}{l}\text { enter } 1 \text { and } 10 \\
\text { milliards }(28 \%)\end{array}$ & \multicolumn{2}{|c|}{ More than 10 milliards $(2 \%)$} \\
\hline $\begin{array}{l}\text { Business Cipher in } \\
95\end{array}$ & $\begin{array}{l}\text { Less than 1Mill } \\
(78 \%)\end{array}$ & $\begin{array}{l}\text { enter } 1 \text { and } 10 \\
\text { milliards }(20 \%)\end{array}$ & \multicolumn{2}{|c|}{ More than 10 milliards (2\%) } \\
\hline The firm age & \multicolumn{2}{|c|}{ Less than 20 years $80 \%$} & \multicolumn{2}{|c|}{ More than 20 years $20 \%$} \\
\hline $\begin{array}{l}\text { Location of the } \\
\text { firm }\end{array}$ & \multicolumn{2}{|c|}{ Region of Sfax (80\%) } & \multicolumn{2}{|c|}{ Region of Tunis (20\%) } \\
\hline $\begin{array}{l}\text { Education level of } \\
\text { the owner }\end{array}$ & Illiterate $(3 \%)$ & Primary $(5 \%)$ & $\begin{array}{l}\text { Secondary } \\
(52 \%)\end{array}$ & \begin{tabular}{|l} 
Higher \\
education \\
$(40 \%)$
\end{tabular} \\
\hline $\begin{array}{l}\text { Education level of } \\
\text { managers } \\
\text { (average) }\end{array}$ & Illiterate $(0 \%)$ & Primairy $(0 \%)$ & $\begin{array}{l}\text { Secondairy } \\
(30 \%)\end{array}$ & $\begin{array}{l}\text { Higher } \\
\text { education } \\
(70 \%)\end{array}$ \\
\hline $\begin{array}{l}\text { The nature of the } \\
\text { respondent }\end{array}$ & \multicolumn{2}{|c|}{ The top manager $(50 \%)$} & \multicolumn{2}{|c|}{ managers $(50 \%)$} \\
\hline $\begin{array}{l}\text { Exportation } \\
\text { experience }\end{array}$ & \multicolumn{2}{|c|}{ Occasionnal Experience $(40 \%)$} & \multicolumn{2}{|c|}{ No experience $(60 \%)$} \\
\hline $\begin{array}{l}\text { Quotation in } \\
\text { financial market }\end{array}$ & \multicolumn{2}{|l|}{ Quoted 0\% } & \multicolumn{2}{|c|}{ Not quoted $100 \%$} \\
\hline
\end{tabular}


4.2 Purification of measures (tests of unidimensionality and reliability)

Three tests of unidimensionality have been applied on the three constructed (IE), (AD) and (PO) namely the factorial exploratory analysis, the test of interrelationship item/ total score, Vernette (1991) and the test of adequacy of the sample of MSA measures or KMO that must pass a doorstep of 0.5 (given by SPSS).

A test of reliability $\alpha$ of Cromback whose requirement is located between 0.8 and 0.9 for an applied survey, Nunally (1967) and Perien, Chérom and Zins (1984).

Details of results of (IE), (AD) and (PO) will be presented in Tables 2, 3 and 4. These tests generated some elimination item and the appearance of derived constructs for (AD) and (PO) following the factorisation so tests of reliability for derived constructs are presenting as follows:
- For (AD), the emergence of three coins constructs, "The competitiveness of suppliers and the technological and commercial advantages of the product" reflected by F1, "The state of the competition" reflected by $\mathrm{F} 2$ and "The state of the demand" underlined by F3. It is compliant to results of Porter (1990).

- For (PO), the emergence of three derived constructs supported by the theory, "proactive motives and the manager's knowledge" reflected by F3, "The reactive motives" reflected by F2 and " The experience in the export "underlined by F1.

Table 2: Purification tests of (INT)

\begin{tabular}{|l|l|l|l|l|}
\hline Items & MSAI & $\begin{array}{l}\text { Correlation item/ } \\
\text { total score }\end{array}$ & $\begin{array}{l}\alpha \text { of the construct if } \\
\text { item deleted }\end{array}$ & $\begin{array}{l}\text { Contribution } \\
\text { in F1 (67\%) }\end{array}$ \\
\hline INT1 & 0.887 & 0.887 & 0.797 & 0.872 \\
\hline INT2 & 0.855 & 0.855 & 0.671 & 0.780 \\
\hline INT3 & 0.887 & 0.885 & 0.684 & 0.783 \\
\hline INT4 & 0.887 & 0.829 & 0.840 & 0.897 \\
\hline INT5 & 0.887 & 0.834 & 0.571 & 0.687 \\
\hline INT6 & 0.887 & 0.883 & 0.775 & 0.853 \\
\hline
\end{tabular}

$\alpha$ of crombach $=0.896 ; \mathrm{MSA}=0.857 ; \mathrm{N}=88$ 
Table3: Purification tests of (AD)

\begin{tabular}{|c|c|c|c|c|c|c|}
\hline Items & MSAi & $\begin{array}{l}\text { Correlation } \\
\text { I/total score }\end{array}$ & $\begin{array}{c}\text { Contribution in } \\
\text { factors : } \\
\text { F1 (28.7\%) }\end{array}$ & $\begin{array}{c}F 2 \\
(19.6 \%)\end{array}$ & $\begin{array}{c}\text { F3 } \\
(4.8 \%)\end{array}$ & $\begin{array}{l}\text { Test of reliability ( } \alpha \text { if } \\
\text { item deleted (after } \\
\text { factorisation) }\end{array}$ \\
\hline AD1 & 0.380 & 0.141 & & 0.543 & & 0.728 \\
\hline $\mathrm{AD} 2$ & 0.686 & 0.07 & & 0.480 & & 0.6752 \\
\hline AD3 & 0.673 & 0.187 & & 0.448 & & 0.676 \\
\hline $\mathrm{AD} 4$ & 0.723 & 0.143 & & 0.637 & & 0.652 \\
\hline AD5 & 0.607 & 0.034 & & 0.301 & & 0.721 \\
\hline AD6 & 0.709 & 0.235 & & 0.502 & & 0.708 \\
\hline AD7 & 0.519 & 0.051 & & 0.316 & & 0.798 \\
\hline AD8 & 0.781 & 0.267 & & 0.655 & & 0.680 \\
\hline AD9 & 0.759 & 0.126 & & 0.498 & & 0.686 \\
\hline AD10 & 0.783 & 0.547 & 0.510 & & & 0.883 \\
\hline AD11 & 0.818 & 0.581 & 0.619 & & & 0.880 \\
\hline AD12 & 0.685 & 0336 & 0.516 & & & 0.887 \\
\hline AD13 & 0.793 & 0.538 & 0.660 & & & 0.880 \\
\hline AD14 & 0.769 & 0.545 & 0.662 & & & 0.879 \\
\hline AD15 & 0.805 & 0.482 & 0.623 & & & 0.882 \\
\hline AD16 & 0.707 & 0.531 & 0.559 & & & 0.884 \\
\hline AD17 & 0.688 & 0.446 & 0.635 & & & 0.882 \\
\hline AD18 & 0.666 & 0.282 & 0.466 & & & 0.889 \\
\hline AD19 & 0.818 & 0.287 & 0.637 & & & 0.884 \\
\hline AD20 & 0.782 & 0.379 & 0.628 & & & 0.883 \\
\hline AD21 & 0.647 & 0.207 & 0.407 & & & 0.892 \\
\hline AD22 & 0.626 & 0.299 & 0.417 & & & 0.888 \\
\hline AD23 & 0.760 & 0.375 & 0.567 & & & 0.886 \\
\hline AD24 & 0.754 & 0.415 & 0.618 & & & 0.882 \\
\hline AD25 & 0.854 & 0.455 & 0.584 & & & 0.883 \\
\hline AD26 & 0.823 & 0.271 & 0.588 & & & 0.885 \\
\hline AD27 & 0.712 & 0.196 & 0.592 & & & 0.886 \\
\hline AD28 & 0.715 & 0.129 & 0.414 & & & 0892 \\
\hline AD29 & 0.622 & 0.04 & & & 0.566 & 0.738 \\
\hline AD30 & 0.738 & 0.138 & & & 0.499 & 0.611 \\
\hline AD31 & 0.650 & 0.199 & & & 0.499 & 0.575 \\
\hline AD32 & 0.677 & 0.127 & & & 0.582 & 0.564 \\
\hline AD33 & 0.673 & 0.150 & & & 0.575 & 0.584 \\
\hline AD34 & 0.782 & 0.08 & & & 0.741 & 0.605 \\
\hline AD35 & 0.510 & 0.329 & & & 0.468 & 0.667 \\
\hline AD36 & 0.553 & 0.258 & & & 0.478 & 0.734 \\
\hline
\end{tabular}

$\alpha$ of crombach for the construct $=0.765 ; \mathrm{MSA}=0.719 ; \mathrm{N}=88$ 
Table 4: Purification tests of (PO)

\begin{tabular}{|c|c|c|c|c|c|c|}
\hline Items & MSAi & $\begin{array}{l}\text { Correlation } \\
\text { I/Total } \\
\text { score }\end{array}$ & $\begin{array}{l}\text { Contribution } \\
\text { in factors : } \\
\text { F1 }(34.4 \%)\end{array}$ & $\begin{array}{l}\text { F2 } \\
(11 \%)\end{array}$ & F3 (7.2\%) & $\begin{array}{l}\text { Test of } \\
\text { reliability ( } \alpha \\
\text { if item } \\
\text { deleted (after } \\
\text { factorisation) }\end{array}$ \\
\hline PO1 & 0.460 & 0.266 & & & 0.289 & 0.586 \\
\hline PO2 & 0.720 & 0.501 & & & 0.272 & 0.488 \\
\hline PO3 & 0.592 & 0.427 & & & 0.674 & 0.446 \\
\hline PO4 & 0.833 & 0.728 & & & 0.284 & 0.483 \\
\hline PO5 & 0.479 & 0.165 & & & 0.436 & 0.565 \\
\hline PO6 & 0.333 & 0.07 & & & 0.261 & 0.631 \\
\hline PO7 & 0.656 & 0.5 & & & 0.469 & 0.516 \\
\hline PO8 & 0.661 & 0.350 & & & 0.301 & 0.687 \\
\hline PO9 & 0.614 & 0.401 & 0.423 & & & 0.889 \\
\hline PO10 & 0.853 & 0.568 & 0.616 & & & 0.880 \\
\hline PO11 & 0.848 & 0.756 & 0.846 & & & 0.872 \\
\hline PO12 & 0.798 & 0.388 & 0.487 & & & 0.884 \\
\hline PO13 & 0.831 & 0.744 & 0.815 & & & 0.875 \\
\hline PO14 & 0.862 & 0.695 & 0.786 & & & 0.875 \\
\hline PO15 & 0.884 & 0.763 & 0.833 & & & 0.871 \\
\hline PO16 & 0.858 & 0.641 & 0.745 & & & 0.876 \\
\hline PO17 & 0.882 & 0.7 & 0.795 & & & 0.871 \\
\hline PO18 & 0.766 & 0.552 & 0.604 & & & 0.880 \\
\hline PO19 & 0.764 & 0.410 & 0.6 & & & 0.881 \\
\hline PO20 & 0.806 & 0.447 & & 0.430 & & 0.552 \\
\hline PO21 & 0.902 & 0.577 & 0.715 & & & 0.880 \\
\hline PO22 & 0.717 & 0.329 & & 0.537 & & 0.550 \\
\hline $\mathrm{PO} 23$ & 0.791 & 0.507 & 0.617 & & & 0.8806 \\
\hline $\mathrm{PO} 24$ & 0.440 & 0.025 & 739 & & & 0.905 \\
\hline
\end{tabular}

$\alpha$ of crombach for the construct $=0.839 ; \mathrm{MSA}=0.773 ; \mathrm{N}=88$

\subsection{Validity of constructs}

"Only the reliable instruments can be validated", Churchill, (1979).

Although various classifications are available, we identify three types of validity, validity of the content, discriminative validity and convergent validity and nomologic validity:

- The validity of the content: is to note that there is not an indication to assure the validity of the content. It is 
about more of a gait: to insure that in terms of content, instruments developed in research are representative of what one tries to measure...Perien and Zins (1984).

- The convergent validity and discriminative validity: The convergent validity is demonstrated for measures of the two constructed (AD) and (PO), knowing that the pvc indications are superior to 0.5 , Fornells and Larker's (1981). The discriminative validity is also demonstrated since constructs are so distinct from one another that the extracted average variance of every construct is superior to the covariance between that construct and another one, Fornell and Larker's (1981).

- $\quad$ Nomologic validity: permits to test the theoretical validity of constructs as well as its conformity with what is conceived by the theory, Vernette (1994).

\section{Results and discussions}

The method chosen according to the objective of research and the nature of variables is the multiple linear regression permitting to identify the degree of explanation of the variation of a dependent variable by the independent variable variation. This method is only applied after a verification of the four conditions of application of a regression, Wheelwrigt and Makridakis (1983).

Two linear regressions have been applied on two groups of the sample, enterprises having an experience in the export and those that never exported. The model for the first group is statistically meaningful to $\mathrm{p}=0.02$, with a $\mathrm{R} 2=0.418$ and a test of Fisher of $2.772>2$. For the second group the model is as meaningful to $\mathrm{p}=0.0001$ with a $\mathrm{R} 2=0.645$ and $\mathrm{a}$ Fisher of $11.683>2$.

\subsection{The differential advantages}

For the experienced businesses the state of suppliers and advantages of products seem to be a necessity to enliven the intention of reexport, the state of the demand is bound negatively to the intention to export. It is generally owing to a stage of mind influenced by logic of production and not of need. In short the state of competitors and especially through their innovations stimulates these businesses to improve their competitiveness to attempt the export. This result is nearly compliant to the one of Eugene and Pasternack (1994). As for businesses that never exported, the differential advantages represent brakes for the intention to export. Thus there is a partial acceptance of the $\mathrm{H} 1$ hypothesis since the differential advantages can be bound positively or negatively to the intention to export. We can find explanations while examining the reality of the Tunisian SME. Indeed, if for the SME already exporters, only the competitiveness of suppliers, the product and the competition and not the pressure of the demand stimulate the intention to export. It is because, in the case of SME, the position of power is occupied mostly by firms rather than by consumers (Only the big firms have a marketing service)

\subsection{The organizational predisposition}

Results of (PO), show that for the first group, reactive motives, proactive motives and knowledge are bound negatively to the export intention. This indicates that for this group, the export is only occasional and non inherent to the offensive or defensive strategies. And managerial knowledge on the foreign markets is very limited. Whereas the past experience, represents a motive to renew the export and indicating a certain satisfaction. As for the second group, proactive motives and knowledge are bound positively to the export intention. It implies that the managers of this group can achieve the expansion of their enterprises only through export, therefore, an organizational change and knowledge on the other markets has proved to be necessary. In the light of these results, the $\mathrm{H} 2$ hypothesis is confirmed.

\subsection{The discerned risk}

The perception of the risk of the foreign business, compared to the one on the local 
market, influences the intention to export, depending on the degree of the exporters satisfaction with their past experience, since those who have never experienced this activity fear this risk of internationalisation. Thus, $\mathrm{H} 3$ hypothesis is confirmed. These results coincide with those of Eugene and Pasternack (1994).

\section{Conclusion}

In a globalized word, the Tunisian SME are invited to build true strategies of internationalisation. Even though export is the fashion generating the least financial and commercial risk, it must be studied in a strategic way and should not result from luck and opportunities. Our SME must find the good remedies to detain the differential advantages and a good organizational predisposition to pull a place in an intensive competitive universe. In this article, we tried to reflect the reality of the Tunisian SME in an international context, It cannot delete the theoretical and empiric limits of this study that we will try to complete in an ulterior research work.

\section{References}

Ajzen and Fishbein. (1980) Understanding attitudes and predicting social behaviour, Englewood Prentice Hall Cliffs, NJ.

Anderson, T. and Black. (1995) Multivariate Data, 4 ème edition, Englewood Prentice Hall.

Axinn. (1988) "Export performance: Do managerial perceptions make a difference?" International marketing review, 5(1), 61-71.

Barker. (1992), “An empirical investigation of differences between initiating and continuing exporters" European Journal of Marketing, 26 (23), 27.

Bauerschmidt. (1985) "Common factors underlying barriers to export: Studies in the US paper Industry", Journal of international business studies, Fall, 111-123.

Bentler.1990 "Comparative fit index in structural models", Psychological Bulletin, 107 Mars, 238-246.
Brooks and Rosson. (1982) A study of export behaviour of small and medium sized manufacturing firms in three canadian provinces, Praeger New York, NY.

Cavusgil. (1984) "Organizational characteristics associated with export activity", Journal of Management Studies, 21 (1), 3-22.

Churchill.1979 "A paradigm for developing better measures of marketing constructs", Journal of Marketing Research, 16 February, 64-73.

Constantines and Morgan. (1994) "Differences in perceptions of exporting problems bases on firm size and export market experiences", European Journal of Marketing, 28, (5), 17.

Dicht, Koglmayer and Muller. (1986) "Identifying export potential: A comparative analysis of German and Japanese firms advances", Marketing International Review, 3 (1), 233-254.

Dicht, Koglmayer and Muller. (1990) "The export decision of small and medium sized firms", Management International Review, 24 (2), 49-60.

Eugene and Pasternack. (1994) "An attitudinal model to determine the export intention of non exporting small manufactures", Marketing International Review, 11 (3), 17-32.

Fornell and Larker's. (1981) “Evaluating structural equation models with unobservable variables and measurement error", Journal of Marketing Research, 18 February, 39-50.

Johnson and Czinkota. (1982) Managerial motivations as determinants of industrial export behaviour, Preager New York, NY.

Johnson and Valne. (1987) "The international processes of the firm, a model of knowledge development and increasing foreign market commitments", Journal of International Business Studies, 1987. 
Jouy. (1993), Stratégor, Stratégie: structure decision, identité, Paris Interédition (2ème édition).

Kauffmann and Schmidt, Cited in Eugene and Pasternack. (1994).

Kauffmann, Manchester and Devies. (1994), "Motivation, management and marketing: An Eastern German case study", European Business Review, 94 (5), p534.

Leonidas Leonidou. (1995) "Export stimulation: A non exporters perspectives" European Journal of Marketing, 29 (8), 1736.

Louter. (1991) "An inquiry in to successful exporting" European Journal of Marketing, $25(6), 7$.

Marsh and Mac Donald. 1988 "Goodness of fit indexes in confirmatory factor analysis: The effect of sample size" Psychological Bulletin, 3 Mai, 391-400.

Nunally. (1967) Psychometric theory, New York MC Graw Hill Book.

Ogram. (1982) Exporters and non exporters: A profile of small manufacturing firmes in Georgia in export management international context, Mr Ginkota and Tesar, New York.

Perien, Cherom and Zins. (1984), Recherche en marketing, (ed) Gaeton Morin. Porter. (1990) The competitive advantage of nations, the free press, New York NY.

Reid. (1982), Cited in Eugene and Pasternack (1994).
Rich. (1997) "The sales manager as arole model: Effects on trusts, job satisfaction and performance of sales people", Journal of the academy of marketing science, 25 (4), 319328.

Tucker and Lewis. 1973 "The reliability coefficient for maximum likelihood factor analysis", Psychometrica 38, March, 1-10.

Vernette. (1991) “L'efficacité des instruments d'études : Evaluation des échelles de mesures", Recherche et Application en Marketing, 6 (3).

Weaver and Pak. (1990), Cited in Eugene and Pasternack (1994).

Weinrauch, Donald and Rao. (1974) "The export marketing mix: An examination of company experiences and perceptions" Journal of Business Research, 2, October, 447-452.

Wheelwright and Macridakis. (1983), Méthodes de prévisions pour la gestion, les éditions d'organisation.

Wiedersheim, Olsen and Welch. (1978) "Pre-export activity: the first step in internationalization", Journal of international Business Studies, 9, Spring Summer, 47-58.

Yang and Alden. (1992) "A market expansion ability approach in identify potential exporters", Journal of Marketing, 56 January, 84-96. 
Appendix 1: Measures of the export intention

a/ Do you have the intention to export in the next 5 years?

\begin{tabular}{|l|l|l|l|l|}
\hline $\begin{array}{l}\text { Very strong } \\
\text { intention } \\
\text { Strong }\end{array}$ & $\begin{array}{l}\text { Strong } \\
\text { intention }\end{array}$ & $\begin{array}{l}\text { middle } \\
\text { intention }\end{array}$ & Weak intention & No intention \\
\hline & & & & \\
\hline
\end{tabular}

b / Did the manager foresee the necessary resources for the expansion of the business?

\begin{tabular}{|l|l|l|l|l|}
\hline $\begin{array}{l}\text { Not at all } \\
\text { okay }\end{array}$ & okay & Undecided & okay & quite okay \\
\hline & & & & \\
\hline
\end{tabular}

c / Is the manager of your enterprise able to exploit all the new opportunities that the market can propose?

\begin{tabular}{|l|l|l|l|l|}
\hline $\begin{array}{l}\text { Not at all } \\
\text { okay }\end{array}$ & okay & Undecided & okay & quite okay \\
\hline & & & & \\
\hline
\end{tabular}

d /Can you specify the frequency of the following activities outside the firm?

\begin{tabular}{|l|l|l|l|l|l|}
\hline & $\begin{array}{l}\text { Very } \\
\text { frequently }\end{array}$ & Frequently & $\begin{array}{l}\text { middle } \\
\text { Frequency }\end{array}$ & $\begin{array}{l}\text { A few } \\
\text { times }\end{array}$ & No time \\
\hline $\begin{array}{l}\text { You participate } \\
\text { in the national or } \\
\text { international } \\
\text { conferences } \\
\text { having for theme } \\
\text { the export }\end{array}$ & & & & & \\
\hline $\begin{array}{l}\text { You subscribe in } \\
\text { the national or } \\
\text { international } \\
\text { magazines } \\
\text { dealing with the } \\
\text { theme of export }\end{array}$ & & & & & \\
\hline $\begin{array}{l}\text { You participate } \\
\text { in national or } \\
\text { international } \\
\text { events } \\
\text { encouraging } \\
\text { exports }\end{array}$ & & & & & \\
\hline
\end{tabular}


Appendix 2: Measures of the differential advantages of the business

\begin{tabular}{|c|c|c|c|c|c|}
\hline & $\begin{array}{l}\text { Not at } \\
\text { all okay }\end{array}$ & okay & Undecided & okay & $\begin{array}{l}\text { quite } \\
\text { okay }\end{array}$ \\
\hline The main competitors & & & & & \\
\hline $\begin{array}{l}\text { Influence the development } \\
\text { of the product }\end{array}$ & & & & & \\
\hline $\begin{array}{l}\text { Have a large enough } \\
\text { setting up }\end{array}$ & & & & & \\
\hline $\begin{array}{l}\text { Have a large investment in } \\
\text { research and development }\end{array}$ & & & & & \\
\hline $\begin{array}{l}\text { Influence the technological } \\
\text { development }\end{array}$ & & & & & \\
\hline $\begin{array}{l}\text { Have very good pictures of } \\
\text { mark }\end{array}$ & & & & & \\
\hline $\begin{array}{l}\text { Are present in the } \\
\text { international exhibitions }\end{array}$ & & & & & \\
\hline $\begin{array}{l}\text { Have access to the capital } \\
\text { through actions that they } \\
\text { detain in stock market }\end{array}$ & & & & & \\
\hline $\begin{array}{l}\text { Their sales increase } \\
\text { quickly }\end{array}$ & & & & & \\
\hline $\begin{array}{l}\text { Have a large range of } \\
\text { products }\end{array}$ & & & & & \\
\hline Your suppliers & & & & & \\
\hline Are innovators & & & & & \\
\hline $\begin{array}{l}\text { Are active in the foreign } \\
\text { markets }\end{array}$ & & & & & \\
\hline Are the leaders & & & & & \\
\hline $\begin{array}{l}\text { Use some advanced } \\
\text { technologies }\end{array}$ & & & & & \\
\hline $\begin{array}{l}\text { Their technologies change } \\
\text { quickly }\end{array}$ & & & & & \\
\hline Have a large setting up & & & & & \\
\hline Are competitive & & & & & \\
\hline $\begin{array}{l}\text { Have developed } \\
\text { knowledge }\end{array}$ & & & & & \\
\hline
\end{tabular}




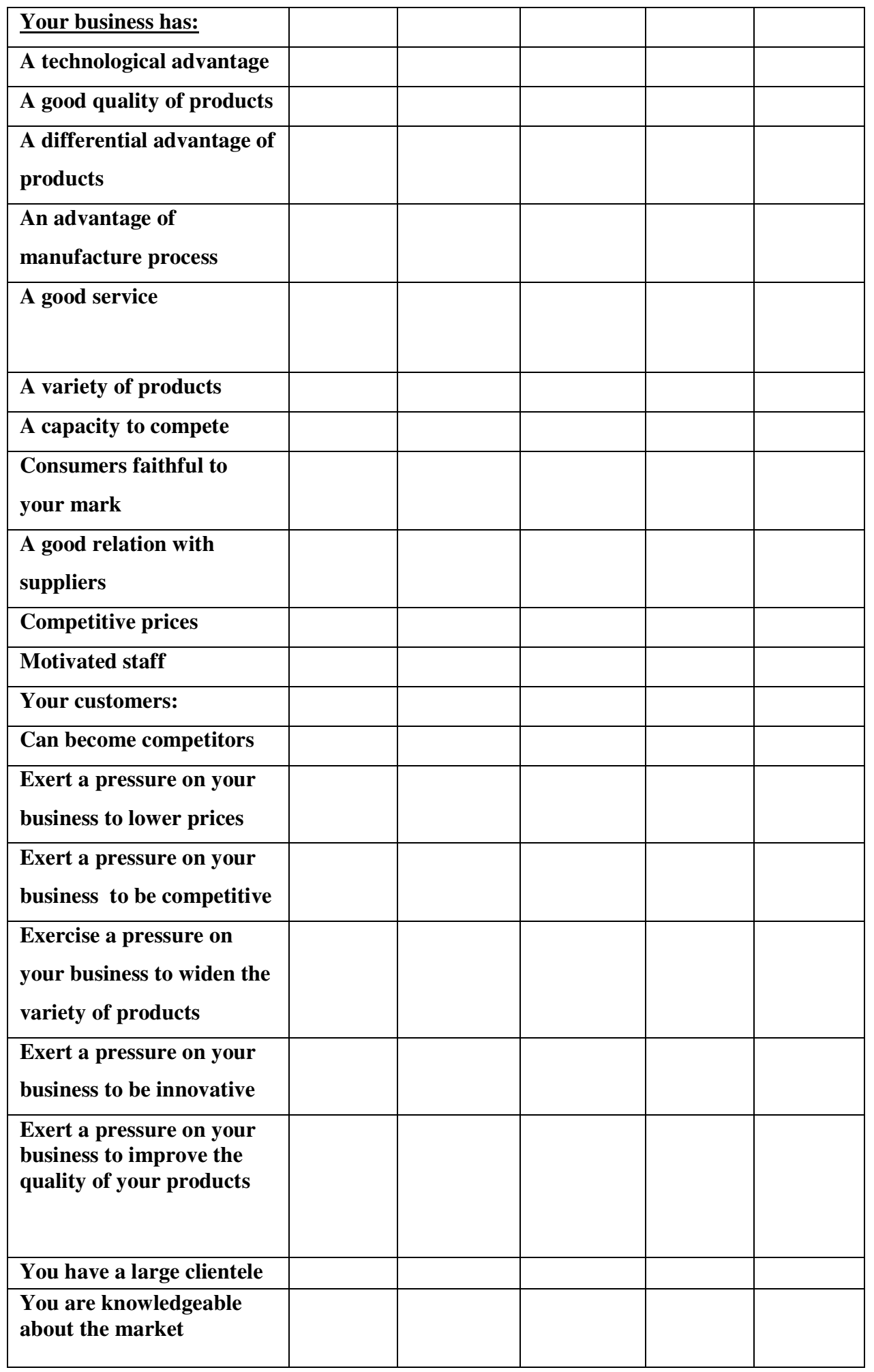


Appendix 3: Measures of the organizational predisposition

\begin{tabular}{|c|c|c|c|c|c|}
\hline & $\begin{array}{l}\text { Not at } \\
\text { all okay }\end{array}$ & okay & Undecided & okay & $\begin{array}{l}\text { quite } \\
\text { okay }\end{array}$ \\
\hline $\begin{array}{l}\text { You export to follow the } \\
\text { example of competitors }\end{array}$ & & & & & \\
\hline $\begin{array}{l}\text { You export to pull a tariff } \\
\text { reduction advantage }\end{array}$ & & & & & \\
\hline $\begin{array}{l}\text { You export following an } \\
\text { intense national } \\
\text { competition }\end{array}$ & & & & & \\
\hline $\begin{array}{l}\text { You export to exploit } \\
\text { opportunities of growth }\end{array}$ & & & & & \\
\hline $\begin{array}{l}\text { You export to compensate } \\
\text { for some negligible } \\
\text { markets by more } \\
\text { important others }\end{array}$ & & & & & \\
\hline $\begin{array}{l}\text { You export to liquidate an } \\
\text { excess of stock }\end{array}$ & & & & & \\
\hline $\begin{array}{l}\text { You export to achieve } \\
\text { some supplementary sales } \\
\text { following the occasional } \\
\text { exports }\end{array}$ & & & & & \\
\hline $\begin{array}{l}\text { You don't export because } \\
\text { the elevated tariffs are } \\
\text { gates to the export }\end{array}$ & & & & & \\
\hline $\begin{array}{l}\text { You export to consolidate } \\
\text { the seasonal fluctuations }\end{array}$ & & & & & \\
\hline $\begin{array}{l}\text { You export to lengthen the } \\
\text { product life cycle }\end{array}$ & & & & & \\
\hline $\begin{array}{l}\text { You export to increase } \\
\text { savings of scales }\end{array}$ & & & & & \\
\hline $\begin{array}{l}\text { You export in order to } \\
\text { contribute to the } \\
\text { expansion in the future }\end{array}$ & & & & & \\
\hline $\begin{array}{l}\text { You export to reduce the } \\
\text { risk by the diversification }\end{array}$ & & & & & \\
\hline
\end{tabular}




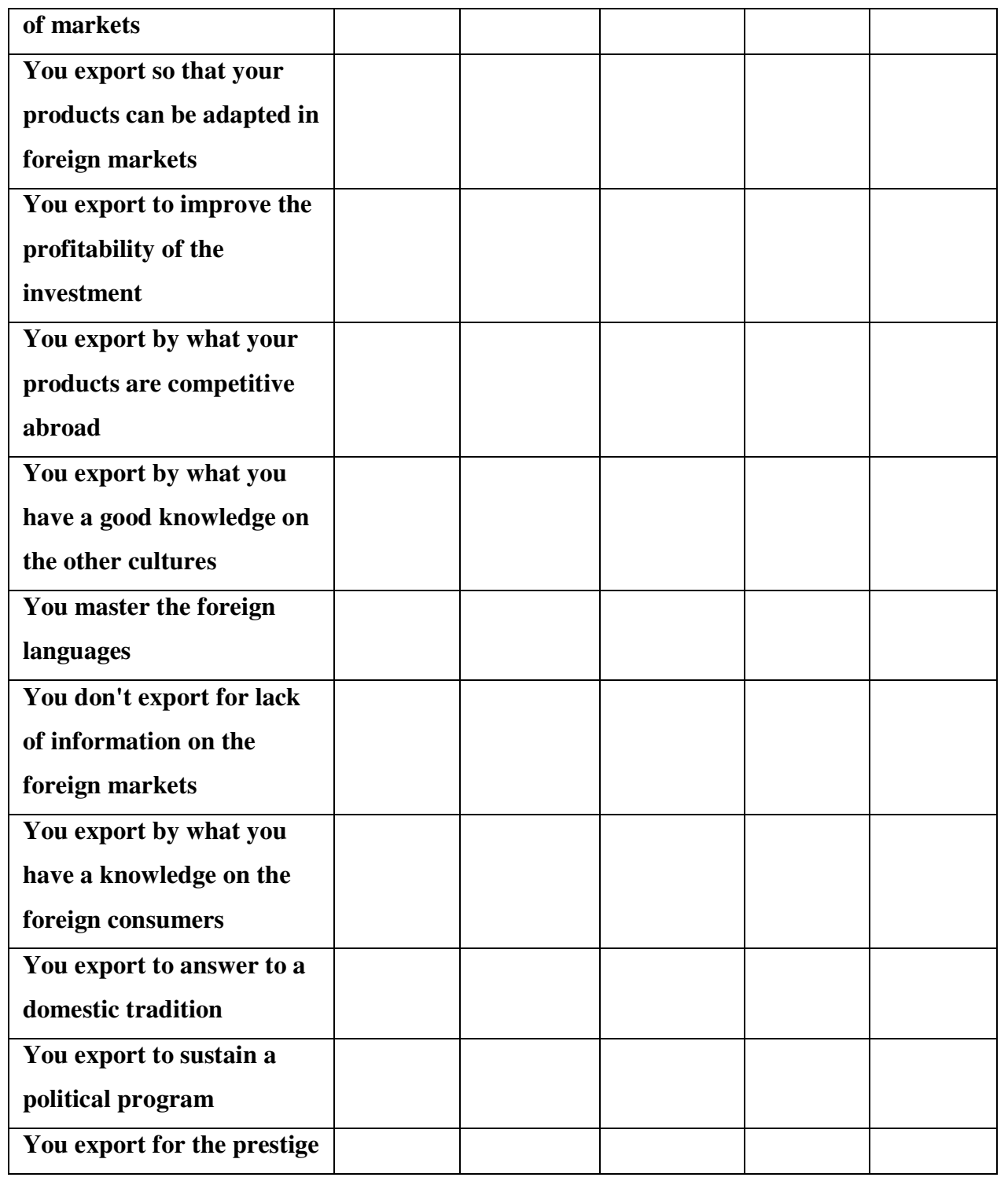

\section{Appendix 4: The measurement of the risk discerned}

The risk of the foreign business compared to the one of the national market is:

\begin{tabular}{|l|l|l|l|l|}
\hline Bigger & big & The same & weak & weaker \\
\hline & & & & \\
\hline
\end{tabular}

